\title{
The effect of inhaled menthol on upper airway resistance in humans: A randomized controlled crossover study
}

\author{
Effie J Pereira BAH, Lauren Sim BScH, Helen S Driver PhD, Chris M Parker MD, Michael F Fitzpatrick MD
}

\author{
EJ Pereira, L Sim, HS Driver, CM Parker, MF Fitzpatrick. The \\ effect of inhaled menthol on upper airway resistance in humans: A \\ randomized controlled crossover study. Can Respir J 2013;20(1): \\ e1-e4.
}

BACKGROUND: Menthol (1-menthol) is a naturally-occurring cold receptor agonist commonly used to provide symptomatic relief for upper airway congestion. Menthol can also reduce the sensation of dyspnea. It is unclear whether the physiological action of menthol in dyspnea reduction is through its cold receptor agonist effect or whether associated mechanical changes occur in the upper airway.

OBJECTIVE: To determine whether menthol inhalation alters upper airway resistance in humans.

METHODS: A randomized, sham-controlled, single-blinded crossover study of inhaled menthol on upper airway resistance during semirecumbent quiet breathing in healthy subjects was conducted. Ten healthy participants (eight female) with a mean $( \pm S D)$ age of $21 \pm 1.6$ years completed the study.

RESULTS: Nasal resistance before testing was similar on both occasions. No differences were found in respiratory frequency (mean \pm SEM) (menthol $17.0 \pm 1.1 \mathrm{cmH}_{2} \mathrm{O} / \mathrm{L} / \mathrm{s}$; sham $16.9 \pm 0.9 \mathrm{cmH}_{2} \mathrm{O} / \mathrm{L} / \mathrm{s}$ ), minute ventilation (menthol $7.7 \pm 0.5 \mathrm{cmH}_{2} \mathrm{O} / \mathrm{L} / \mathrm{s}$; sham $7.9 \pm 0.5 \mathrm{cmH}_{2} \mathrm{O} / \mathrm{L} / \mathrm{s}$ ) or total inspiratory time/total breath time (menthol $0.4 \pm 0.1 \mathrm{cmH}_{2} \mathrm{O} / \mathrm{L} / \mathrm{s}$; sham $\left.0.4 \pm 0.1 \mathrm{cmH}_{2} \mathrm{O} / \mathrm{L} / \mathrm{s}\right)$. The upper airway resistance was similar during menthol $\left(3.47 \pm 0.32 \mathrm{cmH}_{2} \mathrm{O} / \mathrm{L} / \mathrm{s}\right)$ and sham $\left(3.27 \pm 0.28 \mathrm{cmH}_{2} \mathrm{O} / \mathrm{L} / \mathrm{s}\right)$ $(\mathrm{P}=0.33)$ inhalation.

CONCLUSION: Inhalation of menthol does not alter upper airway resistance in awake human subjects.

Key Words: Cold receptor agonist; Menthol; Nasal congestion; Upper airway resistance

M

enthol has been shown to reduce dyspnea in many respiratory conditions (1-3). It is a naturally-occurring cold receptor agonist that specifically activates the transient receptor potential melastatin 8 (TRPM8) channel in the skin and mucous membranes (2). This property induces a cooling sensation that appears to reduce the perception of respiratory effort without actually altering the temperature of the skin or mucous membranes (4-6). Several previous studies have demonstrated an increased sensation of breathlessness in hot, humid conditions (7). To date, it is unclear whether the impact of menthol on dyspnea reduction is simply mediated through cold receptor stimulation or whether associated mechanical changes occur in the upper airway.

Upper airway resistance (UAR) can be modulated through reflex responses. Mechanoreceptors, particularly in the upper airway, can be stimulated through reflex mechanisms by applied negative pressure to induce dilation and stiffening of the upper airway $(8,9)$. One of the challenges of studying upper airway physiology is the difficulty in isolating receptor subtype stimulation - the application of negative pressure causes both intraluminal pressure changes but also associated mechanical displacement of upper airway soft tissues $(9,10)$. Menthol, however, is a selective cold receptor agonist and offers an opportunity to examine the role of cold receptors in isolation. Hence, the aim of the present study was to use inhalation of 1 -menthol to examine the

\author{
L'effet de l'inhalation de menthol sur la résistance \\ des voies respiratoires supérieures chez les humains : \\ une étude transversale aléatoire et contrôlée
}

\begin{abstract}
HISTORIQUE : Le menthol (1-menthol) est un agoniste naturel des récepteurs du froid souvent utilisé pour fournir un soulagement symptomatique de la congestion des voies respiratoires supérieures. Il peut également réduire la sensation de dyspnée. On ne sait pas si l'action physiologique du menthol sur la réduction de la dyspnée s'effectue par son effet d'agoniste des récepteurs du froid ou si des changements mécaniques connexes se produisent dans les voies respiratoires supérieures.
\end{abstract}

OBJECTIF : Déterminer si l'inhalation de menthol altère la résistance des voies respiratoires supérieures chez les humains.

MÉTHODOLOGIE : Les chercheurs ont procédé à une étude aléatoire transversale à simple insu contrôlée contre placebo sur l'effet de l'inhalation de menthol sur la résistance des voies respiratoires supérieures de sujets en santé qui respirent calmement en position couchée. Dix participants en santé (huit femmes), d'un âge moyen ( $\pm E ́ T)$ de $21 \pm 1,6$ ans, ont participé à l'étude.

RÉSULTATS : La résistance nasale avant le test était similaire dans les deux situations. Les chercheurs n'ont constaté aucune différence de fréquence respiratoire (moyenne \pm ÉTM) (menthol 17,0 $1,1 \mathrm{~cm}$ d'eau/L/s; placebo $16,9 \pm 0,9 \mathrm{~cm}$ d'eau/L/s), de ventilation-minute (menthol $7,7 \pm 0,5 \mathrm{~cm}$ d'eau/L/s; placebo $7,9 \pm 0,5 \mathrm{~cm}$ d'eau/L/s) ou de temps inspiratoire total/temps respiratoire total (menthol $0,4 \pm 0,1 \mathrm{~cm}$ d'eau/L/s; placebo $0,4 \pm 0,1 \mathrm{~cm} \mathrm{~d}$ eau $/ \mathrm{L} / \mathrm{s})$. La résistance des voies respiratoires supérieures était similaire pendant l'inhalation de menthol $(3,47 \pm 0,32 \mathrm{~cm}$ d'eau/L/s) et du placebo $(3,27 \pm 0,28 \mathrm{~cm}$ d'eau/L/s) $(\mathrm{P}=0,33)$.

CONCLUSION : L'inhalation de menthol n'altère pas la résistance des voies respiratoires supérieures chez des sujets humains éveillés.

role of the airway cold receptors in modulating UAR in conscious human subjects. We hypothesized that inhalation of 1-menthol in healthy humans, through stimulation of TRPM8 receptors and reflex activation of upper airway dilator muscle function, will effect a reduction in UAR.

\section{Participants}

METHODS

Ten participants were recruited through e-mail and poster advertisements at Queen's University (Kingston, Ontario) campus. All participants were initially screened by interview to exclude those with a history of symptomatic nasal obstruction, or those taking medications that could alter nasal resistance (NR) (eg, antihistamines, vasoconstrictors, vasodilators, topical or systemic steroids and recreational drugs). Participants received a total compensation of $\$ 100$ for completion of the study. The study protocol and consent form were reviewed and approved by the Health Science Research Ethics Board at Queen's University.

\section{Design}

A randomized, single-blinded, sham-controlled crossover design was used to compare the change in UAR while participants were breathing menthol and room air.

Sleep Disorders Laboratory, Kingston General Hospital and Department of Medicine, Queen's University, Kingston, Ontario

Correspondence: Dr Michael F Fitzpatrick, Division of Respiratory Eु Critical Care Medicine, Queen's University, 102 Stuart Street,

Kingston, Ontario K7L 3N6. Telephone 613-548-2379, fax 613-549-1459, e-mail fitzpatm@kgh.kari.net 
TABLE 1

Participant demographics

\begin{tabular}{|c|c|c|c|c|c|c|c|}
\hline \multirow[b]{2}{*}{ Subject } & \multirow{2}{*}{$\begin{array}{c}\text { Age, } \\
\text { years/sex }\end{array}$} & \multirow{2}{*}{$\begin{array}{l}\text { Body mass } \\
\text { index, } \mathrm{kg} / \mathrm{m}^{2}\end{array}$} & \multicolumn{2}{|c|}{ Nasal resistance, $\mathrm{cmH}_{2} \mathrm{O} / \mathrm{L} / \mathrm{s}$} & \multirow{2}{*}{$\begin{array}{c}\text { Forced vital capacity, } \\
\% \text { predicted }\end{array}$} & \multirow{2}{*}{$\begin{array}{c}\text { Forced expiratory volume } \\
\text { in } 1 \mathrm{~s}, \% \text { predicted }\end{array}$} & \multirow{2}{*}{$\begin{array}{c}\text { PNIFR, } \\
\mathrm{cmH}_{2} \mathrm{O} / \mathrm{L} / \mathrm{s}\end{array}$} \\
\hline & & & Menthol & Sham & & & \\
\hline 1 & 22/female & 20.9 & 2.08 & 2.04 & 105 & 128 & 105 \\
\hline 2 & 18/female & 32.8 & 1.95 & 1.75 & 118 & 104 & 130 \\
\hline 3 & 22/female & 20.3 & 2.25 & 2.11 & 105 & 105 & 140 \\
\hline 4 & 22/female & 21.5 & 2.08 & 2.18 & 103 & 119 & 140 \\
\hline 5 & 20/male & 23.3 & 2.32 & 2.77 & 107 & 107 & 150 \\
\hline 6 & 20/female & 20.2 & 2.47 & 2.92 & 106 & 110 & 100 \\
\hline 7 & 22/female & 21.1 & 1.96 & 1.92 & 106 & 95 & 90 \\
\hline 8 & 18/male & 21.8 & 2.95 & 2.73 & 104 & 103 & 110 \\
\hline 9 & 21/female & 21.9 & 2.66 & 2.30 & 103 & 113 & 130 \\
\hline 10 & 21/female & 22.2 & 1.72 & 1.82 & 114 & 119 & 130 \\
\hline
\end{tabular}

PNIFR Peak nasal inspiratory flow rate

Testing was performed on two separate days with a single $24 \mathrm{~h}$ washout period between tests. On one occasion, participants were given menthol to inhale (menthol) and, on the other, room air (sham). The order of menthol and sham was randomly assigned using a computer-generated table of random numbers.

On both days, participants were asked to undergo peak nasal inspiratory flow rate and spirometry measurements to ensure consistency in nasal and lung function during the two test occasions. NR in the seated position was then measured using posterior active rhinometry (11) to verify that it was within normal limits $\left(<5 \mathrm{cmH}_{2} \mathrm{O} / \mathrm{L} / \mathrm{s}\right)$ and consistent between test dates.

Nasal airflow was measured using a heated pneumotach (3700 series, Hans Rudolph, USA) fitted to the inhalation/exhalation port of a nasal continuous positive airway pressure (CPAP) mask. The pneumotach was attached to a separate research pneumotach system (HSS100HR, Hans Rudolph, USA) that provided a digital output of airflow rate as well as breath-by-breath tidal volume. The nasal CPAP mask (Comfort Gel series; Respironics, USA) was carefully fitted to ensure that there was no extrinsic nasal compression and customized to ensure that all exhaust ports on the mask were closed. Supraglottic pressure was measured continuously as per usual protocol (12) by using a 6 Fr infant feeding tube inserted via the naris and into the pharynx, until it was positioned $1 \mathrm{~cm}$ to $2 \mathrm{~cm}$ above the vocal cords. A second 6 Fr infant feeding tube was placed inside the nasal mask, near the anterior naris, and the proximal ends of both tubes were connected to the reference ports of a differential pressure transducer (Ultima, Braebon, Canada). UAR was calculated as the change in pressure between the anterior naris and supraglottic area, as measured through the differential pressure transducer, divided by the change in nasal airflow measured through the pneumotach and standardized to an inspiratory flow rate of $0.3 \mathrm{~L} / \mathrm{s}$ (12). All of the above-mentioned signals were interfaced with a computer montage (Sandman Elite SD $\# 32+$, Embla, USA) to permit simultaneous measurement of airflow, pressure and tidal volume. A two-way nonrebreathing valve of negligible resistance $\left(<0.1 \mathrm{cmH}_{2} \mathrm{O} / \mathrm{L} / \mathrm{s}\right)$ (2630 series, Hans Rudolph, USA) was attached to the pneumotach to separate inspiratory and expiratory airflow - the inspiratory line consisted of low resistance noncompressible CPAP tubing $(91.4 \mathrm{~cm})$ and the expiratory line was left open to the room. A saliva trap $(100 \mathrm{~mL})$ was attached to the inspiratory line, to which $500 \mathrm{~g}$ of crystalline menthol was added on test days. A $500 \mathrm{~g}$ amount of crystalline menthol has been shown to result in a cooling sensation in the airway without causing irritation (3). For the sham arm, the saliva trap was left empty.

Participants were placed in a semirecumbent position with $30^{\circ}$ head elevation for the duration of the study. A research assistant observed subjects continuously during the test periods and communicated with subjects every few minutes to ensure they remained awake. Participants were continuously monitored for $90 \mathrm{~min}$, during three consecutive phases: a 30 min rest period; a 30 min test period; and an additional $30 \mathrm{~min}$ rest period. On completion of the study, participants were asked follow-up questions as to which test day they believed they had received menthol and which test day they found it easier to breathe (for both follow-up questions, participants had to respond either test day 1 or test day 2).

All data were manually scored by a research assistant who was blind to whether the subject was inhaling menthol or sham. A random number generator was used to select 10 random breaths from the final 5 min of each of the three 30 min monitoring periods on each test day, for the measurement of UAR.

\section{Analysis}

A two-way ANOVA with repeated measures was used to compare UAR while breathing sham and menthol, while controlling for order (ie, menthol-sham or sham-menthol). NR values were also plotted to determine compliance with assumptions of normality and variance. The normally distributed data were then further analyzed using paired $t$ tests. $\mathrm{P}<0.05$ was considered to be statistically significant.

\section{RESULTS}

All 10 participants completed the study (eight women, two men), mean $( \pm$ SEM) age $21 \pm 0.5$ years and a mean $( \pm$ SEM) body mass index (BMI) of $22.6 \pm 1.2 \mathrm{~kg} / \mathrm{m}^{2}$. Individual demographic information and respiratory measures are presented in Table 1 . The mean $( \pm$ SEM) BMI for the eight women was $22.6 \pm 1.5 \mathrm{~kg} / \mathrm{m}^{2}$ and $22.5 \pm 0.8 \mathrm{~kg} / \mathrm{m}^{2}$ for the two men. The mean $( \pm$ SEM) forced vital capacity (FVC) \% predicted was 107.1 \pm 1.6 , mean $( \pm$ SEM $)$ forced expiratory volume in $1 \mathrm{~s}\left(\mathrm{FEV}_{1}\right) \%$ predicted was $110.3 \pm 3.1$, and mean $( \pm \mathrm{SEM}) \mathrm{FVC} / \mathrm{FEV}_{1}$ ratio was $105.9 \pm 2.8$. The mean $\left( \pm\right.$ SEM) peak nasal inspiratory flow was $122.5 \pm 6.3 \mathrm{cmH}_{2} \mathrm{O} / \mathrm{L} / \mathrm{s}$. Baseline NR (menthol day $2.2 \pm 0.1 \mathrm{cmH}_{2} \mathrm{O} / \mathrm{L} / \mathrm{s}$; sham day $2.2 \pm 0.1$ $\left.\mathrm{cmH}_{2} \mathrm{O} / \mathrm{L} / \mathrm{s}\right)$ was similar on the two test days $(\mathrm{P}=0.91)$.

Ventilatory data for each participant are presented in Table 2. The mean respiratory frequency (menthol day $17.0 \pm 1.1 \mathrm{cmH}_{2} \mathrm{O} / \mathrm{L} / \mathrm{s}$ versus sham day $\left.16.9 \pm 0.9 \mathrm{cmH}_{2} \mathrm{O} / \mathrm{L} / \mathrm{s}\right)$ was similar on the two test days $(\mathrm{P}=0.87)$. No differences were found in minute ventilation (menthol $7.7 \pm 0.5 \mathrm{cmH}_{2} \mathrm{O} / \mathrm{L} / \mathrm{s}$ versus sham $\left.7.9 \pm 0.5 \mathrm{cmH}_{2} \mathrm{O} / \mathrm{L} / \mathrm{s} ; \mathrm{P}=0.53\right)$ and total inspiratory time/total time (TI/TOT) (menthol $0.4 \pm 0.1 \mathrm{cmH}_{2} \mathrm{O} / \mathrm{L} / \mathrm{s}$ versus sham $\left.0.4 \pm 0.1 \mathrm{cmH}_{2} \mathrm{O} / \mathrm{L} / \mathrm{s} ; \mathrm{P}=0.11\right)$.

The mean $( \pm$ SEM) UAR during menthol inhalation was $3.47 \pm 0.32 \mathrm{cmH}_{2} \mathrm{O} / \mathrm{L} / \mathrm{s}$, and during sham inhalation was $3.27 \pm 0.28 \mathrm{cmH}_{2} \mathrm{O} / \mathrm{L} / \mathrm{s}(\mathrm{P}=0.33)$. There were no significant effects on UAR for treatment order $(\mathrm{P}=0.55)$ or the interaction between treatment and order $(\mathrm{P}=0.70)$. Individual UAR values are presented in Figure 1 and mean $( \pm$ SEM) UAR values in Figure 2. At the end of the study, $70 \%$ of participants accurately identified which day they had received menthol and $90 \%$ of participants reported that they could breathe easier on the menthol test day.

A post hoc power analysis was conducted (13). Based on the observed SD for the difference in UAR between menthol and sham 
TABLE 2

Effect of menthol and sham on ventilation and upper airway resistance

\begin{tabular}{|c|c|c|c|c|c|c|c|c|}
\hline \multirow[b]{2}{*}{ Subject } & \multicolumn{4}{|c|}{ Menthol } & \multicolumn{4}{|c|}{ Sham } \\
\hline & $\begin{array}{l}\text { Respiratory } \\
\text { frequency, } \\
\text { breaths/min }\end{array}$ & $\begin{array}{c}\text { Minute } \\
\text { ventilation, L }\end{array}$ & TI/TOT, units & $\begin{array}{l}\text { Upper airway } \\
\text { resistance, } \\
\mathrm{cmH}_{2} \text { O/L/s }\end{array}$ & $\begin{array}{l}\text { Respiratory } \\
\text { frequency, } \\
\text { breaths/min }\end{array}$ & $\begin{array}{c}\text { Minute } \\
\text { ventilation, L }\end{array}$ & TI/TOT, units & $\begin{array}{c}\text { Upper airway } \\
\text { resistance, } \\
\mathrm{cmH}_{2} \mathrm{O} / \mathrm{L} / \mathrm{s}\end{array}$ \\
\hline 1 & 14 & 7.55 & 0.27 & 2.96 & 14 & 6.62 & 0.35 & 2.52 \\
\hline 2 & 15 & 7.57 & 0.43 & 3.94 & 18 & 7.86 & 0.57 & 3.31 \\
\hline 3 & 14 & 7.27 & 0.42 & 2.62 & 15 & 6.82 & 0.41 & 2.71 \\
\hline 4 & 22 & 8.04 & 0.43 & 2.39 & 21 & 8.14 & 0.41 & 2.27 \\
\hline 5 & 12 & 8.98 & 0.40 & 4.89 & 12 & 7.52 & 0.50 & 4.71 \\
\hline 6 & 15 & 4.26 & 0.49 & 4.91 & 15 & 5.98 & 0.56 & 4.58 \\
\hline 7 & 19 & 8.94 & 0.36 & 2.21 & 21 & 8.72 & 0.34 & 2.36 \\
\hline 8 & 19 & 8.06 & 0.38 & 3.69 & 18 & 8.84 & 0.48 & 3.12 \\
\hline 9 & 19 & 9.86 & 0.32 & 4.17 & 18 & 11.13 & 0.44 & 4.08 \\
\hline 10 & 21 & 6.52 & 0.50 & 2.88 & 17 & 7.46 & 0.39 & 3.07 \\
\hline
\end{tabular}

TI/TOT Total inspiratory time/total time

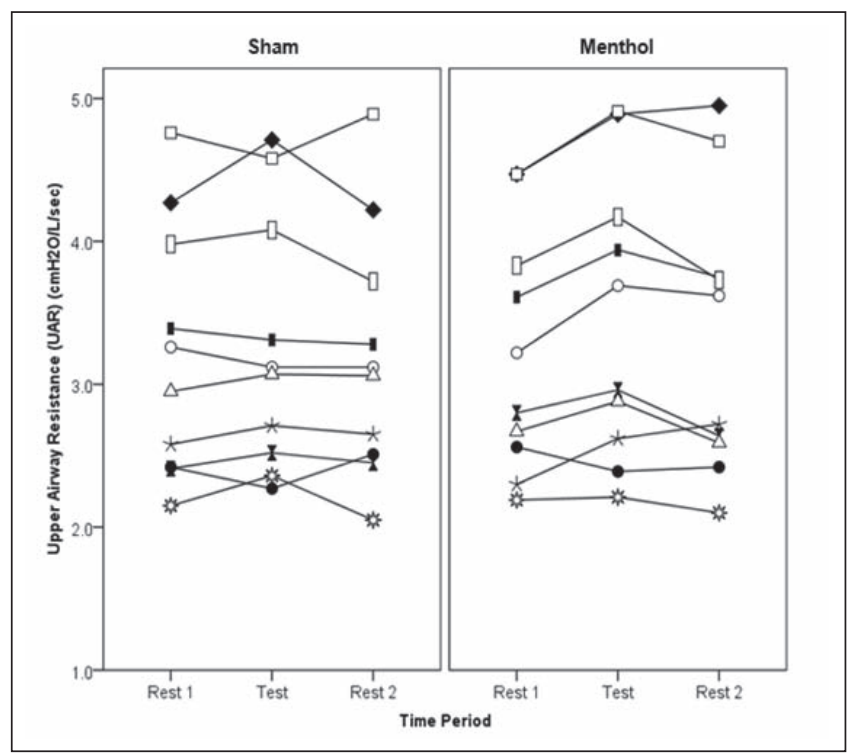

Figure 1) Individual upper airway resistance (UAR) for 10 healthy young adults on a sham day breathing room air and a test day breathing menthol. UAR measurements were made while semirecumbent during the final $5 \mathrm{~min}$ of each of the three $30 \mathrm{~min}$ periods

inhalation, the present study had a statistical power of $98 \%$ to uncover a true difference of $0.5 \mathrm{cmH}_{2} \mathrm{O} / \mathrm{L} / \mathrm{s}(\alpha=0.05)$.

\section{DISCUSSION}

The present study demonstrated that cold receptor stimulation of the upper airway with inhaled menthol does not alter UAR in conscious resting human subjects. The implication of this finding is that the TRPM8 receptor, which mediates the sensation of mucosal cooling in the upper airway, is not implicated in the maintenance of pharyngeal patency by either direct or indirect means. Other authors have demonstrated that nasal menthol inhalation is associated with a subjective sensation of improved airflow, but without any objective change in NR $(1,14,15)$. The current study extends those findings by demonstrating that nasal menthol inhalation is not associated with any significant change in UAR during quiet breathing in healthy, awake participants.

Curran et al (10) demonstrated that cold air inhalation was associated with a decrease in UAR in guinea pigs. Cold air inhalation was associated with a simultaneous increase in geniohyoid activation and a decrease in respiratory frequency, both of which were reversed with local anaesthesia to the upper airway, implying that they were

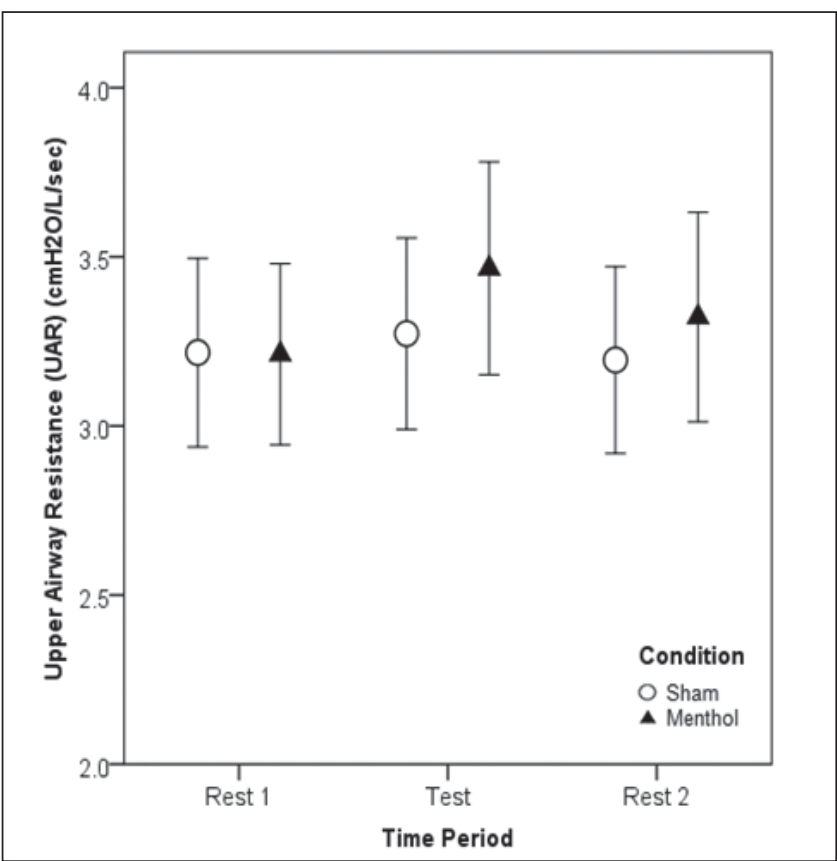

Figure 2) Mean upper airway resistance (UAR) $\pm \mathrm{SEM}\left(\mathrm{cmH}_{2} \mathrm{O} / \mathrm{L} / \mathrm{s}\right)$ in 10 healthy young adults on a sham day breathing room air and a test day breathing menthol while supine. UAR measurements were made while semirecumbent during the final $5 \mathrm{~min}$ of each of the three $30 \mathrm{~min}$ periods

mediated by upper airway reflex activity. Upper airway anaesthesia, however, did not abolish the reduction in UAR induced by cold air inhalation, implying that the mechanism of change in UAR was not primarily through reflex activation of upper airway dilator muscles (10). The absence of any change in respiratory frequency and UAR in our study corroborates this finding and supports the contention that cold air-mediated changes in UAR relate to mucosal vasoconstriction rather than cold receptor-mediated alteration in upper airway diameter.

Menthol inhalation has been shown to have other effects on respiratory control and breathing patterns; however, much of this research has been based on infants and animal models. In neonates, menthol exposure often induces a brief apneic period (16) and, in guinea pigs, inhalation of 1 -menthol and airway cooling were each associated with a reduction in ventilation (17). Studies conducted on healthy adults breathing cold air before a conscious breath-hold demonstrated a reduction in involuntary inspiratory muscle contractions 
during the subsequent breath hold and a prolongation of breath-holding time compared with previous room air inhalation, the effect of which was abolished by topical nasal anaesthetic (18). Cold air inhalation has also been associated with a shortening of inspiratory time and a reduction in tidal volume during carbon dioxide-induced ventilatory stimulation of normal adults (19). In contrast, however, during both resistive and threshold loading of the respiratory system, menthol inhalation was not associated with any alteration in minute ventilation or respiratory timing despite a significant concomitant reduction in subjective respiratory discomfort while breathing menthol compared with room air (3). In the current study, although six of 10 participants experienced a shortening in the total inspiratory time/ total breath time during menthol inhalation, no significant changes in respiratory rate, minute ventilation and TI/TOT were recorded between menthol and room air inhalation. Measurements of UAR were also standardized to a flow rate of $20 \pm 2 \mathrm{~L} / \mathrm{min}$ to avoid confounding by any possible change in respiratory drive or timing induced by menthol (12).

Our study had some limitations that are important to acknowledge. First, we assessed UAR in awake, healthy participants during quiet semirecumbent breathing and, therefore, cannot exclude a potential modulatory effect of menthol on UAR under other circumstances such as during sleep $(20,21)$ or exercise $(22)$. Participants were kept awake and monitored continuously using video monitoring to ensure a consistent position of their head and neck during testing to avoid any confounding changes in UAR induced by changes in neck position $(23,24)$. Second, although the concentration of inhaled menthol was not directly measured in the present study, the dose of crystalline menthol used was chosen on the basis of dose titration before

\section{REFERENCES}

1. Eccles R. Menthol: Effects on nasal sensation of airflow and the drive to breathe. Curr Allergy Asthma Rep 2003;3:210-4.

2. Fisher JT. TRPM8 and dyspnea: From the frigid and fascinating past to the cool future? Curr Opin Pharmacol 2011;11:218-23.

3. Nishino T, Tagaito Y, Sakurai Y. Nasal inhalation of 1-menthol reduces respiratory discomfort associated with loaded breathing. Am J Respir Crit Care Med 1997;156:309-13.

4. Eccles R. Menthol and related cooling compounds. J Phar Pharmacol 1994:46:618-30.

5. Eccles R, Griffiths DH, Newton CG, Tolley NS. The effects of menthol isomers on nasal sensation of airflow. Clin Otolaryngol 1988;13:25-9.

6. Liu B, Qin F. Functional control of cold-and menthol-sensitive TRPM8 ion channels by phosphatidylinositol 4,5-bisphosphate. Neuroscience 2005;7:1674-81.

7. Lamb J, Borycki E, Marciniuk D. Conservation and Fatigue. In: Bourbeau J, Nault D, Borycki E, eds. Comprehensive management of chronic obstructive pulmonary disease. London: BC Decker Inc; 2002.

8. Eckert DJ, McEvoy RD, George KE, Thomson KJ, Catcheside PG. Genioglossus reflex inhibition to upper-airway negative-pressure stimuli during wakefulness and sleep in healthy males. J Physiol 2007;581:1193-205.

9. Mathew OP. Upper airway negative-pressure effects on respiratory activity of upper airway muscles. J Appl Physiol 1984;56:500-5.

10. Curran A, O'Halloran K, Bradford A. Upper airway cooling reduces upper airway resistance in anesthetized young guinea-pigs. Eur Respir J 1998;11:1257-62.

11. Fitzpatrick MF, Driver HS, Chatha N, Voduc N, Girard AM. Partitioning of inhaled ventilation between the nasal and oral routes during sleep in normal subjects. J Appl Physiol 2003;94:883-90. the commencement of the study, with $500 \mathrm{mg}$ crystalline menthol being the minimum dose required to provide a consistent sensation of airway cooling without concomitant irritation (3). Third, blinding of participants was not possible because menthol has a distinctive odour that is readily perceived when inhaling at the concentrations used in the present study; participants, however, were not aware of the underlying hypothesis, and the individual recording the UAR measurements remained blind to the treatment or sham status of the experimental condition.

\section{CONCLUSION}

The present study evaluated the effects of menthol inhalation on UAR in healthy human participants, without nasal congestion, while awake during quiet breathing. Menthol inhalation was not associated with any change in ventilation and UAR, suggesting that cold receptor stimulation does not modulate UAR in awake human subjects.

ACKNOWLEDGEMENTS: MFF designed the research study, HSD provided technical support, and EJP and LS performed the research and analyzed the data. This work was supported by research grants from the Ontario Thoracic Society, William M Spear Foundation, Queen's University, and Clinical Teachers Association at Queen's University. The authors thank the staff at the Sleep Disorders Laboratory at Kingston General Hospital, Kingston, Ontario.

DISCLOSURES: The authors have no financial disclosures or conflicts of interest to declare.

12. McLean HA, Urton AM, Driver HS, et al. Effect of treating severe nasal obstruction on the severity of obstructive sleep apnea. Eur Respir J 2005;25:521-7.

13. Altman DG. How large a sample? In: Gore SM, Altman DG, eds. Statistics in Practice. London: British Medical Association; 1982.

14. Eccles R, Jones AS. The effect of menthol on nasal resistance to air flow. J Laryngol Otol 1983;97:705-9.

15. Naito K, Ohoka E, Kato R, Kondo Y, Iwata S. The effect of L-menthol stimulation of the major palatine nerve on nasal patency. Auris Nasus Laryn 1992;18:221-6.

16. Javorka K, Tomori Z, Zavarská L. Protective and defensive airway reflexes in premature infants. Physiol Bohemoslov 1980;29:29-35.

17. Orani GP, Anderson JW, Sant'Ambrogio G. Upper airway cooling and 1-menthol reduce ventilation in the guinea pig. J Appl Physiol 1991;70:2080-6.

18. McBride B, Whitelaw WA. A physiological stimulus to upper airway receptors in humans. J Appl Physiol 1981;51:1189-97.

19. Burgess KR, Whitelaw WA. Effect of nasal cold receptors on pattern of breathing. J Appl Physiol 1988;64:371-6.

20. Fitzpatrick MF, McLean H, Urton AM, Tan A, O'Donnell DE, Driver HS. Effect of nasal or oral breathing route on upper airway resistance during sleep. Eur Respir J 2003;22:827-32.

21. Hudgel DW, Hendricks C. Palate and hypopharynx - sites of inspiratory narrowing of the upper airway during sleep. Am Rev Respir Dis 1988;138:1542-7.

22. Wheatley JR, Amis TC, Engel LA. Oronasal partitioning of ventilation during exercise in humans. J Appl Physiol 1991;71:546-51.

23. Amis TC, O'Neill N, Wheatley JR. Oral airway flow dynamics in healthy humans. J Physiol 1999;515:293-8.

24. Thut DC, Schwartz AR, Roach D, Wise RA, Permutt S, Smith PL. Tracheal and neck position influence upper airway airflow dynamics by altering airway length. J Appl Physiol 1993;75:2084-90. 


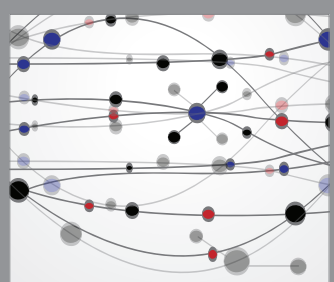

The Scientific World Journal
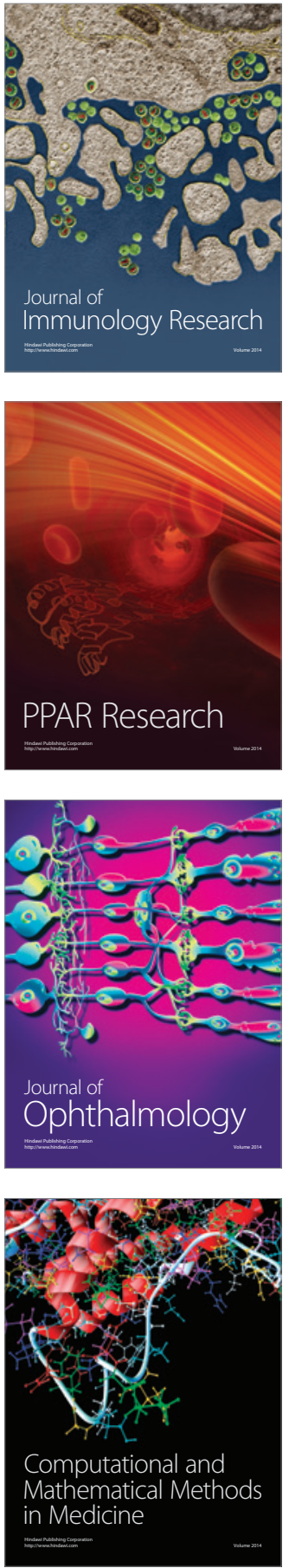

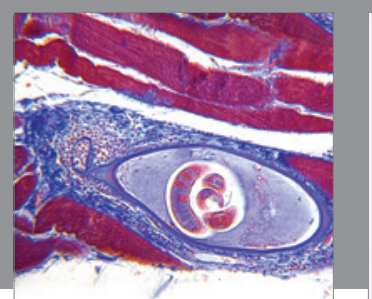

Gastroenterology Research and Practice

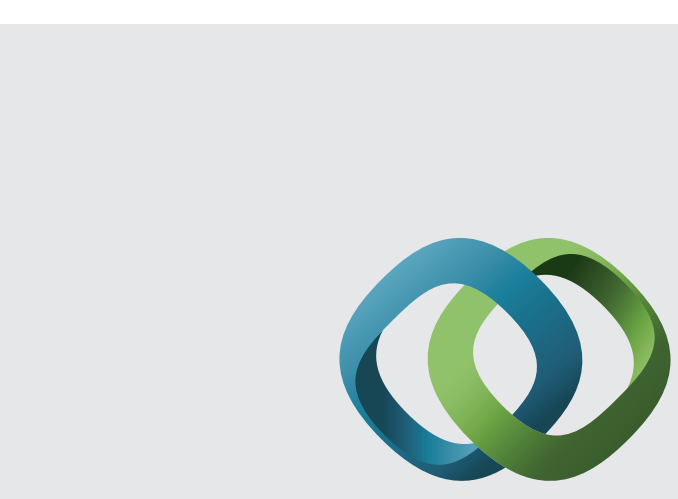

\section{Hindawi}

Submit your manuscripts at

http://www.hindawi.com
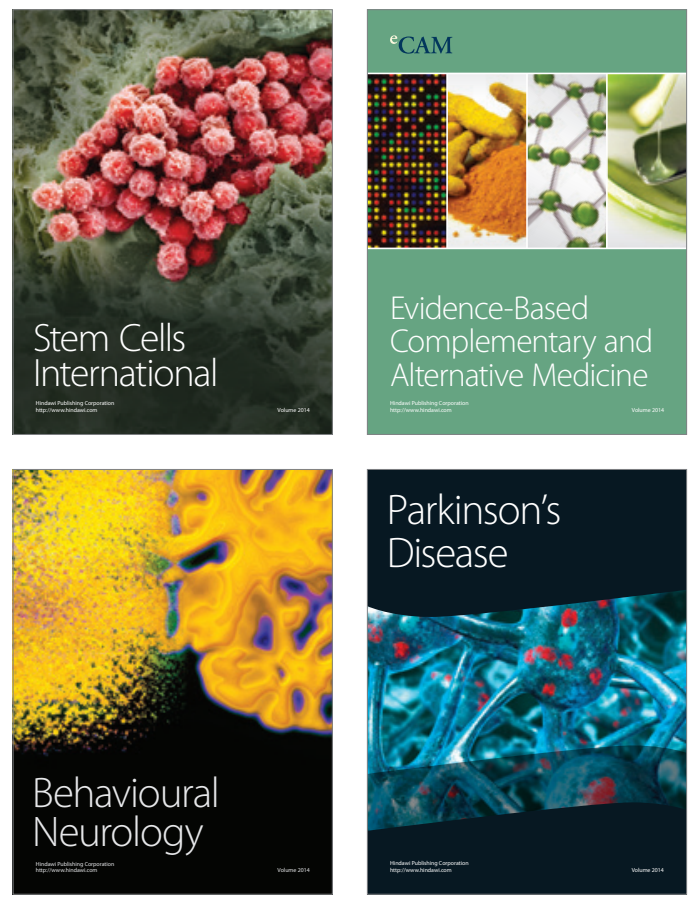
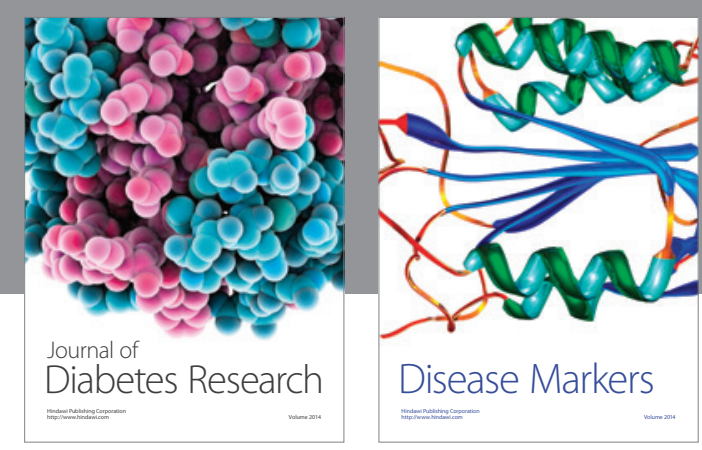

Disease Markers
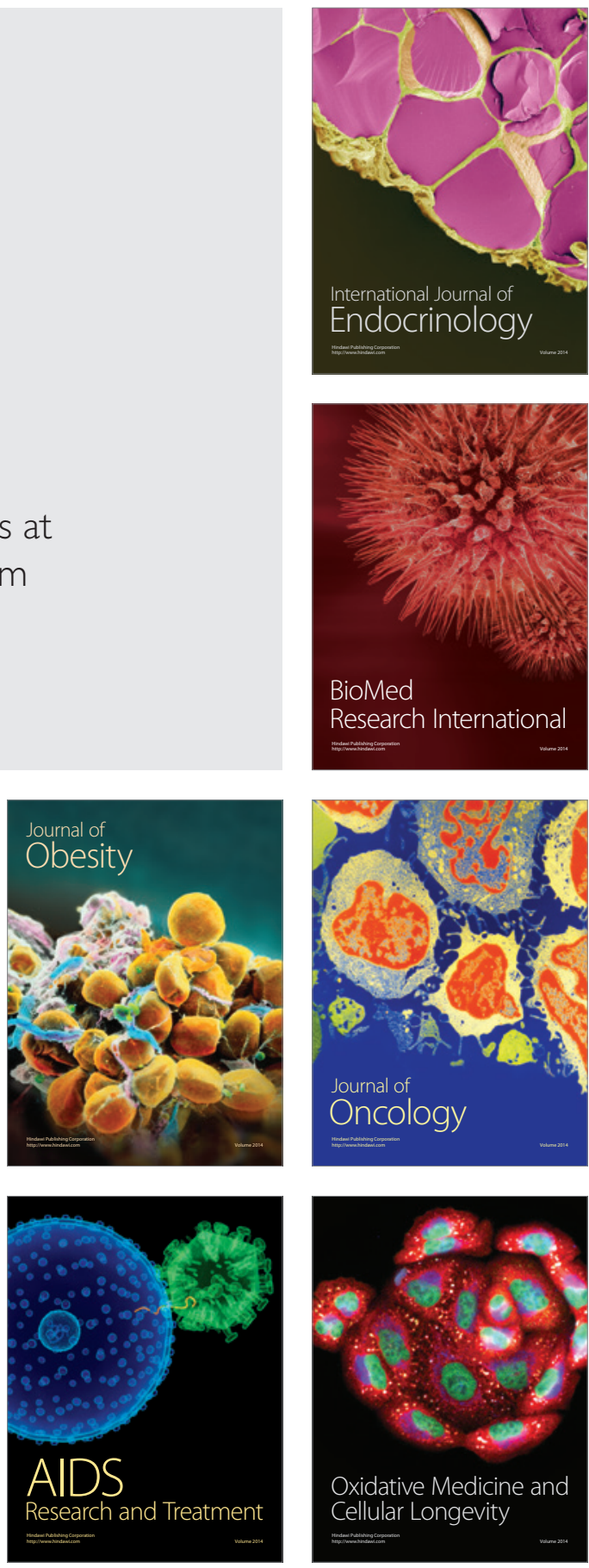